\title{
The Biological and Pharmacological Importance of Apricot
}

\author{
Ismet Yilmaz* \\ Inonu University, Faculty of Pharmacy, Department of Pharmacology, Malatya,Turkey
}

Received: October 13, 2017; Accepted: December 06, 2017; Published: January 19, 2018

*Corresponding author: Ismet Yilmaz, Assistant Professor, Inonu University, Faculty of Pharmacy, Department of Pharmacology, 44280, Malatya/Turkey, E-mail: yilmaz.ismet@inonu.edu.tr

\begin{abstract}
The aim of this review can be summarized as medicinal importance of apricot and it's kernel. In this context; to give information on some research results which hitherto intended it's biological and pharmacological importances. It's different effects from liver regeneration to myocardial ischemia- reperfussion and serum minerals to anti-oxidant enzymes will be discussed. It may be emphasized that apricot is one of the rarest fruits which consumes both itself and it's kernel.
\end{abstract}

Key word: Apricot (Prunus armeniaca L.)

\section{Introduction}

In this review; content and dieatary importances, antioxidant/ protective effects, and also phtochemical and biological properties of apricot and its kernel may be better given as not subheadings.

In last two decades, researches have been focused on fruit consumption which contains carbohydrate, fat and proteins as well as vitamins, minerals and essential fatty acids that have an effect on body functions. Therefore, nutritionists set up fruits in second step of the food pyramid and fruit consumption has been recommended [1, 2]. There are a lot of important information about different fruits from many reports. But our aim was making a review only on apricot and it's kernel. Many reports can be found about pharmacological and biological effects of apricot. Here we will give a short information by summarizing the results of these studies. Of course, to obtain more information, these articles should be detailly examined.

Apricot and it's kernel have antiparasitic, anticancer, antiaging, antiatherosclerosan, antianginal, cardio/hepato/ renoprotective and antioxidant (especially $\beta$-caroten) effects. It has various minerals (especially $\mathrm{K}, \mathrm{Fe}, \mathrm{Mg}, \mathrm{P}$ and $\mathrm{Se}$ ), vitamines (A, C and E). It is a rich fiber source and has also sedative, antispasmotic, antisestradial, antimicrobial, antimutagenic, antitussive, antiinflammatory, antinociceptive, enzyme inhibitory and tonic effects have been emphasised by many researchers [310]. Hovewer, a special attention has been given to flavonoids and their beneficial effects in diseases such as cardiovascular and cerebrovascular, some forms of cancer and Parkinson's and Alzheimer's diseases. The main flavonoids in the samples of apricot (Prunus armeniaca L.) are; quercetin-3-rutinoside, quercetin-3-galactoside and quercetin-3-glucoside [11].

About cultivation and marketing statistics of apricot in Malatya province were given by Parlakpinar et al [12]. The phenolics, minerals, vitamins, lipids and carbohidrate contents of apricot may be differantiate by altitude, apricot species and genetic, soil structure and used fertilizers [5, 6]. In Malatya, widely cultivated apricot varieties are Zerdali, Çataloğlu, Çöloğlu, Hacıhaliloğlu, Hasanbey, Soğancı, Kabaaşı, Çekirge, Ethembey, İsmailağa, Hacıkız, Alyanak and Tokaloğlu [13-18].

In rats, cardioprotective activity of apricot-feeding has been reported as related to it's antioxidant phenolic contents [12]. Apricot and/or $\beta$-carotene treatment may protect the impairment of oxidative stress and ameliorate methotrexate (MTX)-induced intestinal and kidney damage $[19,20]$. The effects of sun-dried organic apricot (SDOA) supplementation to rat chow on some serum mineral levels (at four different rates and three different periods) on both genders of rats were reported by Yllmaz et al [21]. According o them, there was an increase in serum $K$ and declines in serum $\mathrm{Ca}, \mathrm{Mg}$ and $\mathrm{P}$ levels and no significant differences in serum $\mathrm{Na}$ and Fe levels. Compared to rat chow, SDOA is poorer in mineral contents except $\mathrm{K}$. The most suitable rate was $1 \%$ SDOA and the most suitable period is 30 days. The differences between $\mathrm{P}$ levels of male and Fe levels of female rats migth be due to gender [21]. In addition, they reported that, $1 \%$ rate and 120 days period of SDOA consumption showed beneficial effects for each gender of rats (especially on red blood cells (RBC), hemoglobin (HgB) and hematocrit (HCT)). They also emphasized that the results may have a significance for therapy, preservation and/or eradication of some types of anemia in humans [22]. When the rates of SDOA in diet were increased, they reported that significant decreases were observed in all parameters of males and in alkalinphosphatase (ALP), acetyltransferase (AST) and total protein (TP) of females. An effective role was observed on albumin (Alb), alkalintransferase (ALT) and TP levels in both genders. Hovewer, there were no significant coactions between rates and periods. The rate of $1 \%$ has a beneficial effect on all above parameters in both genders of rats [23]. They also reported that, $2.5 \%$ and $5 \%$ rates of SDOA on male rats and $10 \%$ rate on female rats have a significant positive effect in their daily food intake proportions [24]. Further, they reported that after 70 $\%$ partial hepatectomy (PH), 5\% SDOA supplementation and 
21 days feeding periods had useful effects on the regenerative capacity of residual liver [25]. In another study, Yllmaz et al reported that, before 7 and after 10 days of $\mathrm{PH}$, silymarin application had benefical effect than SDOA consumption on renewal of remnant liver of rats [26]. It was underline that, reduction in both telomerase activity and oxidative stress might indicate the benefical effects of apricot (sun dried and sulfur fumigated apricot consumption) against the damege caused by azoxhymethane in rats [27].

Yllmaz et al also reported that, at least $1 \%$ rate and 30 days period of SDOA consumption showed beneficial effects on the levels of oxidative stress enzymes such as superoxide dismutase (SOD), malondialdehyde (MDA), catalase (CAT), glutathione (GSH) and glutathione-S transferase (GST) of large intestines for both genders of rats [28]. In another two studies by Yllmaz et al, it has been declared that 5\% SDOA had hepatoprotective effects opposite to acute acetaminophen (APAP) overdose [29] and against to ketamin-induced hepatotoxicity [30]. Öztürk et al reported that, long-term apricot feeding showed beneficial effects on CCl4-induced liver steatosis and injury in rats owing to its high radical-scavenging capacity. It is possible to say that apricot as a native food could have helpful effect on nonalcoholic hepatic steatosis [31]. Ugras et al reported that after low-dose irradiation on testis tissue of rats, $20 \%$ rate of apricot diet significantly improved the oxidative status. This protective effect was evident when the diet continued throughout the course and initiated after exposure [32]. Similar results were noticed by Kurus et al as apricot rich diet may have a protecting role on histopathological changes produced by alcohol in rat testes [33] and have a favorable effect in the treatment of renal diseases [34]. The contents of rat chow and apricot have been given in their reports [24, 32]. Yurt and Celik declared that, sun and sulphiteddried apricot and it's kernel may have a protective effect on some detoxificative enzymes due to alcohol exposure in rats. They concluded that apricot had a hepatoprotective effect against ethanol, it is likely acting by exalting the antioxidative defense systems [35]. On the other hand, apricot kernel is a prominent natural resource of antioxidants like tocopherols and phenolic compounds [36]. It has been reported that the vitamines (A, C, $\mathrm{E}$ and $\beta$-carotene) and Se ingredients of apricot displayed some differentiations in the fresh and sulphur-dried production, postharvest procedure, height of region, cultivar or brutal types and also among cultivars [37]. Ruiz et al determined the differences among apricot varieties and their pulp color and phenolic combination (as procyanidins and anthocyanins) by using HPLC. They reported that total phenolic content was different between 32.6 and $160.0 \mathrm{mg} / 100 \mathrm{~g}$ of edible tissue and no relation between the pulp color and the phenolic content [38]. On the other hand, same author emphasized that apricot color had a large impact not only on consumer sensation but also on nutritional spotting for it's vitamin A content [39]. Different rates of apricot extracts exhibited an antibacterial activity, but did not exhibit any antifungal activitiy. Additionally, extracts of apricot kernels and kernel peel did not show any antimicrobial activity [40]. On the other hand, there is a dilemma; Yiğit et al accentuated that the strongest antibacterial activity was traced in methanol and water distils of bitter kernels and in methanol distils of sweet kernels against Gram-positive bacteria. Additionally, the methanol distils of the bitter kernels were very strong against the Gramnegative bacteria. Significant anticandida efficiency was also observed with the methanol distils of bitter apricot kernels. High antioxidant activity existed in particularly sweet kernel extracts [4]. They detected crude oil, dry matter, crude protein, crude fiber and mineral contents and some physical features such as mass, length, width, thickness and terminal velocity of apricot kernels. They underlined that all kernels had high amounts of $\mathrm{Ca}$, K, Na and $\mathrm{P}$. Therefore, apricot kernel may be handy for the assessment of nutritional info and oil source [17]. Vitamines (A, C and E) and MDA contents of apricot dried by micro-wave drier are more influential than infrared drier [41].

Miyazawa et al reported that the Japanese apricot (Prunus mume) had an inhibiting effect on the colonization of $H$. pylori in gastric mucosa and gastritis (but inhibition mechanism of this preparation is not clear) [3]. It has been reported by Jaya and Lamba that the most potent antibacterial activity was observed in the ethanolic extract of fruits against $S$. aureus and B. subtilis. Additionally, the ethanolic extract was powerful against $P$. vulgaris and E. coli. Substantial activity against Candida albicans was also seen with ethanolic distil. The ethanolic extract showed more considerable antimicrobial activity as compared to water distil [42]. In same study, it was reported that the antitubercular effect of water and ethanol distils prepared from fruits of Prunus armeniaca (L.) appreciated on M. tuberculosis and ethanolic distil had more prominent antitubercular activity as compared to water distil [43]. In another similar study, the distil showed good antimicrobial efficiency against Gram-positive bacteria which dry apricot is a decent source of health supporting constituents which can be used for therapeutic intent [9]. It has been underlined that a substantial amount of polyphenol oxidase enzyme was distiled from the Igdır apricot [44]. Hacıseferoğulları et al searched several nutritional contents (as ash, crude oil, crude protein, crude fiber) of six apricot sorts of water soluble distil/alcohol soluble distil, and mineral (K, P, $\mathrm{Ca}, \mathrm{Na}$ and $\mathrm{Mg}$ ) contents of quite ripen apricot fruits. They underlined that these knowledge may be good for the estimation of nutritional state of apricot fruit [13].

It has been reported that dry matter, sugar (as the major sugars sucrose, glucose, and fructose) and sorbitol content of Malatya apricot kinds are importantly higher than others. Malatya apricots were found to be a good source of phenolic compounds and malic acid as the heavy organic acid. They emphasized that the $\mathrm{K}$ content of Malatya apricots was considerable high and these apricots were major sources of $\mathrm{Mg}, \mathrm{Zn}$, and Se. Malatya apricots contain functional ingredients with high nutritional stature [15]. In nine apricot kinds, the whole oil substances of apricot kernels were between 40.23 and 53.19\%. Turan et al reported that oleic acid contributed $70.83 \%$ of total fatty acids, chase by linoleic (21.96\%), palmitic (4.92\%), and stearic (1.21\%) acids [14]. In another study, the elements existing in seed oil were detected and apricot has been found as rich for $\mathrm{P}, \mathrm{Ca}, \mathrm{Mg}, \mathrm{Fe}$ and $\mathrm{Cu}$, and seed oil also comprised oleic acid (73.58\%), linoleic acid (19.26\%), palmitic acid (3.31\%), myristic acid (1.18\%) and 
stearic acid (2.68\%) [45]. It was noticed that apricot kernel oil causes improvements in liver antioxidan status of rats in collation to sunflower oil which is an usually consumed vegetable oil [46]. In another study, it was reported that apricot kernel distils can improve colon inflammation and ulcers excited by trinitrobenzene sulfonic acid (TNBS), in a tentative model of colitis in rats. Different real components and mechanisms may be confused in these good effects, thus more particular studies are needed for more proper statements [11]. In a near-time study, it has been emphasised that, before colonoscopy adding stewed apricot juice to senna increased patient comfort and improved bowel cleansing and no adverse effects [47]. And also, it is reported that, in rats $500 \mu \mathrm{g} /$ $\mathrm{kg}$ /day acrylamide was detoxified by the liver without resulting any liver tissue damage and acrylamide+SDOA consumption did not change any significant molecular, histopathological and biochemical parameters of the liver [48].

In rats, hepatoprotective effect of apricot leaf distill against paracetamol-induced liver toxicity has been approved by histopathological investigations of liver tissues [49]. Uğur et al emphasized that flavonoids of apricot leaves are chlorogenic acid, rutin, catechin and naringin. According to the growth season, while rutin and catechin (chlorogenic acid, in some apricot species) levels showed an increase, but chlorogenic acid of other some apricot species and naringin levels showed exponentially decrease [18]. Additionally, amygdalin which is naturally present in apricot kernels and after eating, it converts to cyanide. Cyanide was also determined in apricot, almond, peach and apple seeds and studies indicated that $0.5-3.5 \mathrm{mg} / \mathrm{kg}$ bw cyanide can be lethal, but normal apricot consumption does not pose a health risk to consumers. It has actively been promoted intake of 10 to 60 kernels per day for general population and patients with cancer [50].

\section{Conclusions}

1. Daily fruit consumption should not be neglected.

2. It should be avoid no consume of fruits and consume too much.

3. At least, daily $1 \%$ (3-4 pcs/day) consumption can be recommended with a clear conscience.

4. It should pay attention to consumption of different fruits, especially local ones.

5. Although the leaves of plants and some fruits are not consumed by humans, it is important to determine beneficial substances in leaves for synthesis and present them to the duty of human health.

6. Apricot is one of the rarest fruit that consumes both itself and its kernel.

Finally, in this review, as we have underlined in abstract, our goal was to summarize the medicinal/pharmacological importance of apricot and it's kernel. Therefore, it has been limited to in vivo and in vitro results of some studies about nutritional and pharmacological importance of apricot and it's kernel. On the other hand, we hope that this article may be helpful for further studies.

\section{References}

1. Georgiou NA, Garssen J, and Witkamp RF. Pharma-nutrition interface: The gap is narrowing. Eur J Pharmacol 2011;651(1-3): 1-8. doi: 10.1016/j.ejphar.2010.11.007

2. Kahlon TS and Smith GE. In vitro binding of bile acids by bananas, peaches, pineapple, grapes, pears, apricots and nectarines. Food Chem. 2007;101(3):1046-1051.

3. Miyazawa M, Utsunomiya $H$, Inada $K$, Yamada T, Okuno $Y$, Tanaka $H$, et al. Inhibition of Helicobacter pylori motility by (+)-Syringaresinol from unripe Japanese apricot. Biol Pharm Bull. 2006;29(1):172-173.

4. Yiğit D, Yiğit N, and Mavi A. Antioxidant and antimicrobial activities of bitter and sweet apricot (Prunus armeniaca L.) kernels. Brazil J Med Biol Res. 2009;42(4):346-352.

5. Yılmaz İ. Antioksidan içeren bazı gıdalar ve oksidatif stres. J Turgut Ozal Med Cen. 2010;17(2):143-153.

6. Yllmaz İ. Karotenoidler. J Turgut Ozal Med Cen. 2010;17:223-231.

7. Erdoğan-Orhan İ, Kartal M. Insights into research on phytochemistry and biological activities of Prunus armeniaca L. (apricot). Food Res Inter. 2011;44(5):1238-1243.

8. Raj V, Jain A, Chaudhary J. Prunus Armeniaca (Apricot): An overview. J Pharm Res. 2012;5(8):3964-3966.

9. Sharma S, Satpathy G, Gupta RK. Nutritional, phytochemical, antioxidant and antimicrobial activity of Prunus armenicus. J Pharmacog Phytochem. 2014;3(3):23-28.

10.Minaiyan M, Ghannadi A, Asadi M, Etemad M and Mahzouni P. Antiinflammatory effect of Prunus armeniaca L. (Apricot) extracts ameliorates TNBS-induced ulcerative colitis in rats. Res Pharm Sci. 2014;9(4):225-231.

11.Miguel G, Dandlen S, Neves A and Antunes D. Flavonoids content of different apricot (Prunus armeniaca L.) cultivars. 4th IASME/WSEAS International Conference on Energy, Environment, Ecosystems and Sustainable Development (EEESD'08). 2008.

12.Parlakpınar H, Olmez E, Acet A, Ozturk F, Tasdemir S, Ates B, et al. Beneficial effects of apricot-feeding on myocardial ischemiareperfusion injury in rats. Food Chem Toxicol. 2009;47(4):802-808.

13.Hacıseferoğulları H, Gezer İ, Özcan MM, Asma BM. Post harvest chemical and physical-mechanical properties of some apricot varieties cultivated in Turkey. J Food Process Eng. 2007;79(1):364-373.

14.Turan S, Topcu A, Karabulut I, Vural H and Hayaloglu AA. Fatty Acid, Triacylglycerol, Phytosterol, and tocopherol variations in kernel oil of Malatya apricots from Turkey. J Agric Food Chem. 2007;55(26):1078710794.

15.Akin EB, Karabulut I, Topcu A. Some compositional properties of main Malatya apricot (Prunus armeniaca L.) varieties. Food Chem. 2008;107(2):939-948.

16.Ercisli S, Agar G, Yıldırım N, Esitken A and Orhan E. Identification of apricot cultivars in Turkey (Prunus armeniaca L.) using RAPD markers. Romanian Biotech Letters. 2009;14(4):4582-4588.

17.Gezer İ, Hacıseferoğulları H, Özcan MM, Arslan D, Asma BM, Ünver A. Physico-chemical properties of apricot (Prunus armeniaca L.) kernels. South West J Hortic Biol Environ. 2011;2:1-13.

18.Uğur Y, Erdoğan S, Yilmaz İ. Variation of quantitative composition of phenolic compounds in the apricot (Prunus armeniaca L.) leaves 
during the growth seasons. (Unpublished data; Poster presentation in International Conference: 10th Aegean Analytical Chemistry Days, 2016; 29.09-02.10/2016, Çanakkale/Turkey).

19.Vardi N, Parlakpinar H, Ozturk F, Ates B, Gul M, Cetin A, et al Potent protective effect of apricot and $\beta$-carotene on methotrexateinduced intestinal oxidative damage in rats. Food Chem Toxicol. 2008;46(9):3015-3022. doi: 10.1016/j.fct.2008.05.039

20.Vardi N, Parlakpınar H, Ates B, Cetin A, Otlu A. The protective effects of Prunus armeniaca L (apricot) againist methotrexate-induced oxidative damage and apoptosis in rat kidney.J Physiol Biochem. 2013;69(3):371381. doi: $10.1007 / \mathrm{s} 13105-012-0219-2$

21.Yllmaz I, Temel I, Gursoy S, Dogan Z, Turkoz Y. Effects of sun dried organic apricot on some serum mineral levels in rats. Int Res J Pharma. 2012;2:62-67.

22.Yllmaz I. Effects of sun dried organic apricot on some hematological parameters in rats. J Pharm Res. 2012;1:18-22.

23.Yllmaz I, Temel I, Gursoy S, Dogan Z. The effects of apricot on serum proteins and liver enzymes in rats. J Food Nutr Res. 2013;52:101-106.

24.Yllmaz I, Doğan Z, Soysal H. The effects of dried apricot supplementation on daily food intake in rats. Turk J Pharma Sci. 2013;10:137-144.

25.Yilmaz İ, Karaman A, Vardi N, Cetin A, Erdemli E. Effects of organic apricot on liver regeneration after partial hepatectomy in rats. Transplant Proceed 2013;45(6):2455-2460. doi: 10.1016/j transproceed.2013.04.005

26.Yilmaz I, Hatipoglu HS, Taslıdere E, Arabacı T, Karaaslan. Comparing the regenerative effects of Silymarin and Apricot on liver regeneration after partial hepatectomy in rats. (Unpublished data; Poster presentation in 11th International Symposium on Pharmaceutical Sciences (ISOPS), 2015a; 09-12/06/2015, Ankara, Turkey).

27.Karabulut AB, Ozgor D, Gurocak S, Karadag N, Otlu O and Colak C. Comparision between the effects of dietary supplements of sun dried and sulfur fumigated apricots on the telomerase activity and oxidative stress parameters in azoxhymetane administered rats. 2014;6(5):5055.

28.Yllmaz İ, Doğan Z, Erdemli E, Gursoy S, Bag HG. The effects of apricot on large intestine oxidative stress enzymes in rats. Eur J Pharma Med Res. 2015;6(2):503-512.

29.Yllmaz İ, Cetin A, Bilgic Y. Hepatoprotective effects of apricot against acetaminophen induced acute hepatotoxicity in rats. Am J Pharma Sci. 2015;3(2):44-48. DOI: 10.12691/ajps-3-2-3

30.Yllmaz I, Eröksüz H. Hepatoprotective effects of apricot againist ketamin-induced hepatotoxicity in rats. (Unpublished data; Oral presentation in International Conference on Medicinal and Pharmaceutical Chemistry, 2016; 05-07 December, 2016 Dubai/UAE).

31.Ozturk F, Gul M, Ates B, Ozturk IC, Cetin A, Vardi N, et al. Protective effect of Apricot (Prunus armeniacea) on hepatic steatosis and damage induced by carbon tetra chloride in Wistar rats. Br J Nut. 2009;102(12):1767-1775. doi: 10.1017/S0007114509991322

32.Ugras MY, Kurus M, Ates B, Soylemez H, Otlu A, Yilmaz İ. Prunus armeniaca L (apricot) protects rat testes from detrimental effects of low-dose x-rays. Nutr Res. 2010;30(3):200-208. doi: 10.1016/j. nutres.2010.03.001

33.Kurus M, Ugras M, Ates B, Otlu A. Apricot ameliorates alcohol-induced testicular damage in rat model. Food Chem Toxicol. 2009;47(10):26662672.

34.Kurus M, Taslıdere E, Elbe H, Uğraş M, Otlu A. Protective effects of
Prunus armeniaca L. (apricot) on low dose radiation-ınduced kidney damage in rats. Turk Neph Dial Transpl. 2014;23(2):105-111.

35.Yurt B and Celik I. Hepatoprotective effect and antioxidant role of sun, sulphited-dried apricot (Prunus armeniaca L.) and its kernel against ethanol-induced oxidative stress in rats. Food Chem Toxicol. 2011;49(2):508-513. doi: 10.1016/j.fct.2010.11.035

36.Durmaz G and Alpaslan M. Antioxidant properties of roasted apricot (Prunus armeniaca L.) kernel. Food Chem. 2007;100(3):1177-1181.

37.Munzuroglu 0, Karatas F, and Geckil H. The vitamin and selenium contents of apricot fruit of different varieties cultivated in different geographical regions. Food Chem. 2003;83(2):205-212.

38.Ruiz D, Egea J, Gil MI, Tomas-Barberan FA. Characterization and quantitation of phenolic compounds in new apricot (Prunus armeniaca L.) varieties. J Agric Food Chem. 2005;53(24):9544-9552.

39.Ruiz D, Egea J, Tomas-Barberan FA, Gil MI. Carotenoids from new apricot (Prunus armeniaca L.) varieties and their relationship with flesh and skin color. J Agric Food Chem. 2005;53(16):6368-6374.

40.Alan Y, Atalan E, Erbil N, Zorver F, Kiycak G, Çiçek Aİ. Antimicrobial Activities of Malatya Apricot (Prunus armeniaca L.) and Apricot Kernels. J Anatol Natur Sci. 2013;4:60-69.

41.Karataş F, Kamışlı F. Variations of vitamins (A, C and E) and MDA in apricots dried in IR and microwave. J Food Process Eng. 2007;78(2):662668.

42.Jaya S, Lamba HS. Antimicrobial activity of fruits of Prunus armeniaca (L.). J Drug Deliv \& Therap. 2012;2:163-166.

43.Sehgal J, Siddheswaran P, Kumar KLS and Karthiyayini T. Antitubercular activity of fruits of Prunus armeniaca (L.). Inter J Pharm Bio Sci. 2010;1(2):1-4.

44.Demir H, Çimen Ç, Çelikezen FÇ. Purification and characterization of polyphenol oxidase enzyme from Iğdır apricot (Prunus armeniaca L.). Bitlis Eren University J Sci Tech. 2012;2(1):22-26.

45.Bachheti RK, Rai I, Joshi A and Rana V. Physico-chemical study of seed oil of Prunus armeniaca L. grown in Garhwal region (India) and its comparison with some conventional food oils. Int Food Res J. 2012;19(2):577-581.

46.Kutlu T, Durmaz G, Ates B and Erdogan A. Protective effect of dietary apricot kernel oil supplementation on cholesterol level and antioxidant status of liver in hypercholesteremic rats. J Food Agric \& Environ. 2009;7(3and4):61-65.

47.Yasar B, Abut E, Kayadibi H, Akdogan F, Gonen C. Adding stewed apricot juice to senna improves quality of colon cleansing in preparation for colonoscopy. Functional Foods in Health and Disease. 2017;7(1): 5467.

48.Erdemli ME, Sahin N, Turkoz Y, Yilmaz I, Cinar K, Akgoz M, et al. The possible hepatoprotective effect of apricot against acrylamide induced hepatotoxicity in rats. J Turgut Ozal Med Cen. 2017;24(1):48-53. doi: 10.5455/jtomc.2016.12.125

49.Raj V, Mishra AK, Mishra A, Khan NA. Hepatoprotective effect of Prunus armeniaca L. (Apricot) leaf extracts on Paracetamol induced liver damage in Wistar rats. Pharmacognosy J. 2016;8:154-158. DOI:10.5530/pj.2016.2.9

50.Apricot kernels pose risk of cyanide poisoning. EFSA. 2016. 